\title{
LINGUISTIC PREJUDICE IN TEACHING PRACTICE
}

\author{
PRECONCEITO LINGUÍSTICO NA PRÁTICA DE ENSINO
}

\author{
Rosemari Lorenz Martins', Cíntia de Moura Pinto2 \\ Rachel Carlesso ${ }^{3}$, Alex Sandro Maggioni Spindler ${ }^{4}$ \\ Jéssica Luana Bueno dos Santos 5 , lago Ramon Möller 6
}

\author{
Recebido em: 28 de junho de 2017 \\ Aprovado em: 09 de agosto de 2017 \\ Sistema de Avaliação: Double Blind Review \\ RCO | a. 10 | v. 1 | p. 128-136 | jan./jun. 2018 \\ DOI: https://doi.org/10.25112/rco.v1i0.1314
}

\begin{abstract}
This article deals with the investigation of the presence of linguistic prejudice in teaching practice, in which, supposedly, high school teachers would be presuming students' performance from the use or lack of use of the standard language in speech within the school environment. The research and the production of this work was based on Marcos Bagno's work, a relevant name on the debate on linguistic prejudice, besides other works of sociolinguists and articles on the problem of linguistic prejudice in the classroom, from what it was made a methodology that consists of the application of a questionnaire interview. The analysis of results, opened to the several possibilities of reading produced from the ambiguity and contradiction of the results, made it possible to find positive and negative points as well as new possibilities of research around the same subject. It was concluded, however, that the tendency in school environment is marginalizing the use of the language that does not meet educational standard language and pointing it as the ideal model to be reached, what reinforces the central hypothesis of this work.
\end{abstract}

Keywords: Sociolinguistics. Linguistic variation. Linguistic prejudice. Adequacy.

\section{RESUMO}

O presente artigo debruçou-se sobre a investigação da presença do preconceito linguístico na prática docente, em que, hipoteticamente, professores do Ensino Médio pressupõem o desempenho dos estudantes a partir do uso ou não do uso da língua padrão na fala no ambiente escolar. A partir de uma reflexão sobre a obra de Marcos Bagno, nome relevante no debate sobre preconceito linguístico, além de produções de sociolinguistas e artigos sobre o preconceito linguístico na sala de aula, executou-se uma metodologia calcada, essencialmente, na aplicação de uma entrevista guiada por questionário. A análise de resultados, na medida em que se abriu para as várias possibilidades de leitura produzidas da ambiguidade e da contradição dos resultados, foi capaz de encontrar pontos positivos, pontos negativos e novas possibilidades de pesquisa no mesmo tema. Concluiu-se, porém, que a tendência no ambiente escolar é de marginalização da língua não culta utilizada pelos alunos e da visão que a língua padrão é o modelo ideal que se pretende alcançar, o que reforça, portanto, a hipótese central deste estudo.

\footnotetext{
${ }^{1}$ Doutora em Letras pela Pontifícia Universidade Católica do Rio Grande do Sul (Porto Alegre/Brasil). Professora na Universidade Feevale (Novo Hamburgo/Brasil). E-mail: rosel@ feevale.br.

${ }^{2}$ Mestranda em Letras na Universidade Feevale (Novo Hamburgo/Brasil). E-mail: cintiademourap@ feevale.br.

${ }^{3}$ Mestranda em Letras na Universidade Feevale (Novo Hamburgo/Brasil). Professora no Colégio LaSalle São João (Novo Hamburgo/Brasil). E-mail: rachel.carlesso@gmail.com.

${ }^{4}$ Graduado em Letras (Português/Inglês) pela Universidade Feevale (Novo Hamburgo/Brasil). Professor no SESI - Serviço Social da Indústria. E-mail: alexmaggioni@feevale.br.

${ }^{5}$ Graduanda em Letras (Português/Inglês) na Universidade Feevale (Novo Hamburgo/Brasil). E-mail: jessicabueno@feevale.br.

${ }^{6}$ Graduando em Letras (Português/Inglês) na Universidade Feevale (Novo Hamburgo/Brasil). E-mail: iago.moller@gmail.com.
} 
Palavras-chave: Sociolinguística. Variação linguística. Preconceito linguístico. Adequação.

\section{INTRODUCTION}

Whether on public spaces or in the media, one can perceive a circulation of discourses related to a very old practice of prejudice that has started being debated in universities only few times ago: the linguistic prejudice. Marcos Bagno, one of the most scholars on the subject, perceived and researched this relationship of Brazilians with the language and he has published, in 1999, a book called "Preconceito Linguístico - o que é, como se faz". In the book, the author proves the existence of the specific practice of prejudice insofar as it analyzes common-sense discourses and individuals' posture about language in different contexts of communication. It is clear, therefore, the problem is:

[...] fed daily in television and radio programs, in newspaper and magazine columns, in books and manuals intended to teach what is" right "and what is" wrong, "not to mention, of course, in traditional teaching instruments of language: normative grammar and textbooks (BAGNO, 2007, p. 13, our translation).

One of the strategies to solve the problem of prejudice is the approach of the theme in the classroom, since it is a school, and also a space where one of the aims is to teach citizenship. For example, a new perspective on language using, encompassing informal variations and expressions as legitimate forms of communication in different contexts, being this the concept of adequacy. From this point, it is understood that in schools it is necessary to teach standard language to pupils, making it clear how it works and when it is necessary to be used, but not teaching that other ways of saying derived from a varied language cannot be used (TRAVAGLIA, 2007).

If linguistic prejudice is perceived on common sense and in the media, including adolescents and young people's discourses, it is possible to suppose that many educators, besides not approaching the theme feelingly, they are, maybe, contributing to the stigmatization of speech variations, insofar as they themselves lead the prejudiced stance in the school environment. The main hypothesis that eventually emerges from the facts is the existence of teachers who presuppose students' performance from using or not using the standard language in speech. More questions come naturally from the assumption: How does linguistic prejudice show itself? How is it possible for the researcher identify it on school environment? What would the results of a scientific research show, besides corroborating or refuting the initial hypothesis?

To answer these and other questions, it is necessary to substantiate the research on strong basis, what means to resort to the work of theorists and researchers on linguistic prejudice and Sociolinguistic. The theoretical basis will allow the reader to understand the concept of linguistic prejudice, the dimension of the problem as well as the differences among prejudiced and intolerant practices, and what stance that should be adopted concerning to this in class.

\section{THEORETICAL FOUNDATION}

The definition of prejudice in Dicionário Priberam da Língua Portuguesa on line, which presents it "as an idea or concept precipitately formed and without a serious or impartial basis or an unfavorable opinion that is not based on objective data, provides very little or none condition for any appreciative interpretation of the word" (2008-2013, our translation). At the same time, the pejorative perception of the word is corroborated by numerous studies that relate prejudice, discrimination, exclusion, and violence. 
Faced with a society that is increasingly attentive to social multiplicities and more aware of the needs to regulate several aspects involved in the social relationships that result from it (Bandeira \& Batista, 2002), new concepts are bound to occur for manifestations of prejudice still not debated, because it is the delimitation of different types of prejudice into concepts what allows the insertion of these subjects in studies, debates and, finally, in the public agenda. Among these new definitions is the "linguistic prejudice." Since it is a new expression, and consequently, confusing, it is necessary to unfold its meaning.

A meaningful outline, from Marli Quadros Leite's work called "Prejudice and intolerance in language" (our translation), and mentioned, by Bessa (2015), in the article "Intolerance against the linguist without common sense discourse" (our translation), presents "linguistic prejudice" as

[...] silly and sneaky discrimination that the individual may have in relation to the language of the other: it is a dislike, an ugliness, or misconstruction of a use (or language), without discussion about the contrary, of what could be beautiful or correct. It is a dislike without clear discursive action on the fact rejected (LEITE apud BESSA, 2015, p. 51, our translation).

Although there is a distinction between prejudice and linguistic intolerance, it is important to notice the intrinsic relation between these two concepts: though not every linguistic prejudice takes the form of an act of linguistic intolerance, and it is true that the second has been always temped by the first. Intolerance is a more explicit form of discrimination than prejudice because it is characterized as verbal aggression and it does not affect only the language, but also the speaker itself (BESSA, 2015).

Linguistic prejudice, like other types of prejudice, comes from historical and social nature and is conducted by power ratio. That can be seen in the discourses of common sense and in the social, institutional, and administrative relations that interest the instances of power (MARIANI, 2008). This is very clear in the posture of radio, television and printed media aimed at teaching "right" and "wrong" ways to use the language. Traditional teaching instruments as normative grammar and textbooks, which should operate in the opposite direction, corroborates this dichotomous perception of language, which stigmatizes informal language (BAGNO, 2007, p. 14).

This set of factors constructs a "mythology of linguistic prejudice". These myths are materialized in discourses such as "the Portuguese language spoken in Brazil presents a surprising unit", "the place where the best spoken Portuguese in Brazil is in Maranhão", "people need to know grammar in order to speak and write well" or, perhaps, the most serious of them and a sign of the problematic relation that many Brazilians have with their own language is, "the domain of cultured norm is an instrument of social ascension" (BAGNO, 2007, p. 14, our translation).

An exploration of each of the myths concomitant with historical and literary research denotes a lack of scientific foundation in all kinds of discourses, motivated however by political issues. It is also possible to talk about politics, since political reflection cannot be far from the theoretical positions and practical attitudes of citizen, teacher, and scientist (BAGNO, 2007).

The variations of the standard Portuguese spoken in Brazil in relation to the spoken Portuguese in Portugal have phonetic, syntactic, lexical, and semantic differences beyond the use of the language itself, variations that by themselves demonstrate the ordinary nature of the changes that occur in any language. If the language spoken in Brazil is accepted as standard, even if it varies in so many aspects in relation to its native language, why could not the variations occurring in the informal or non-standard sphere of using language be accepted as appropriate? The linguistic varieties come from different natures: historical, geographic, and sociocultural, and therefore, "there is no language in the world that 
is uniform and homogeneous" (SANTANA; JESSÉ; NEVES; MARIA apud BAGNO, 2007, p. 27, our translation).

Analogous to that, the word "language" should not be used as a determined, abstracted, regular, homogeneous system of rules or immanent linguistic relations, but for a heterogeneous, variable, historical and social phenomenon which, both syntactically and semantically, depends on its production conditions and manifests itself in concrete situations of using. When the school does not consider a language in its entirety, in addition to the risk of affecting students' self-esteem, it tries to prevent the natural language transformations. Treat the PNP (non-standard Portuguese - our translation) and its variations as incorrect and linguistically deficient, it is like blocking them from being realized in the relations between writing and context (MARCUSCHI, 2007).

Despite the efforts of Brazilian Department of Education, considering the existence of this type of prejudice, creating a school committed to opposing the "mythology of linguistic prejudice", and recognizing cultural diversity and linguistic variety, Bagno's work (2007, our translation) makes it clear that even traditional language teaching instruments often act to increase prejudice. As Bandeira \& Batista (2002) step up "prejudice, usually incorporated and believed, is the heart and the most effective reproducer of discrimination and exclusion, hence violence" (p. 126, our translation), the society that aims to diminish social inequality and violence cannot ignore or be conformed to the linguistic prejudice issue.

Concerned about this problem, several Linguistic researchers deal with the investigation of the existence of linguistic prejudice in the school environment and the possible consequences on the students' development. These ones, are included Da Silva \& Da Silva (2015), that in their article "Language prejudice in school: how to prevent?" (our translation), present a study produced at Alberto Torres School, located in Porto de Moz/PA, Brazil. Based on a qualitative study, the authors verified that not only the existence of linguistic prejudice in the school environment, manifested in the teachers' discourses and beliefs and in the interaction among teachers and students in the classroom, but also in the interference of that behavior in the development and students' learning, therefore,

[...] being victims of linguistic prejudice, students are affected by negative feelings that diminish their self-esteem and motivation to want to learn and participate in classes, transforming themselves into individuals with an inferiority complex, which can disrupt individuals' intellectual and professional growth (p. 32, our translation).

So, it is important to be attentive to the students' needs and to the linguistic prejudice, because being reasonable on classroom and school may affect the students more than teachers can realize about them. Standard language can be taught objectifying introducing learners into the different social spheres, and making them capable to communicate effectively wherever they are, but variation on language cannot be ignored or marginalized, whereas that people live in different contexts and it is usual vocabulary adequacy in different contexts as well.

\section{METHOD}

According to Prodanov (2013), by method "we can understand the path, the form, the way of thinking. It is the approach to the level of realizing the abstraction of phenomena. It is the connection between processes and mental operations on research" (p. 26, our translation). Then, this study, also through a reflexive and qualitative research, understood such as "a category of research which has as its object the study of a unit of in-depth form, being able to be treated of a subject, a group of people or a 
community" (PRODANOV, 2013, p. 60, our translation), has devoted, with a bibliographical review of authors on sociolinguistics subjects, such as Bagno (2007), Tarallo (2010), and Marcuschi (2007), the aim of this work is to understand opinions and essays of a group of high school's teachers in relation to their students considering the fact that linguistic variations are often overlooked in the school environment, the place where linguistic prejudice should be fought.

The interviewed informants of the research were teachers of several public schools at Vale do Paranhana/RS, Brazil, who have different academic backgrounds, teach distinct subjects nearing. In addition, all of them have been teaching for at least three years in high school grade classes. The selection of teachers from different subjects and school contexts is justified in order to have a more varied sampling range, attesting to a way that teachers are dealing with the issue of linguistic variation in general school context, not only in one institution and among educators of some subjects or with a degree of background, for example.

Thus, the instruments were a questionnaire have been designed to identify traits of prejudice in relation to the linguistic variation of students in the classroom. For doing this, the following steps have been followed: elaboration of the questions and preparation of the questionnaire; application of the question to the teachers; gather and analyse the results; and the analysis of the results. It is also important to notice that an interview has been divided into two parts: one of them has been to collect information about the teachers through a participation form and the other to record teachers' answers to the questions of the questionnaire, which have been used for the final analysis.

\section{RESULTS AND ANALYSIS}

The process of analysis of the results in this research faced two challenges regarding the corpus. The first one is the cautious and guarded posture that the interviewee can assume during the interview, which would influence their responses and damage the analysis of the results. It has been necessary, then, the formulation of strategies to neutralize the force exerted by the interviewer's presence (Tarallo, 2010). One of them, is the avoidance of the expression "linguistic prejudice" in conversations, statements and interviews related to the research. Other, is the formulation of questions with wide and free possibilities of answer, even in those present suggestions for answers. Still about the first strategy, the aim was to convey the idea that the research is about students' speech and writing conditions and not about the teacher's attitude towards them, giving space to the interviewees, freely speak, and argue against the ideas contained in the interview free of judgment worries.

The second challenge has been to understand what could be behind the interviewees' discourses, with possibilities ranging from ignorance of concepts, in which interviewees might have difficulty on interpreting the questions and, consequently, on answering them, until conscious or indirect manifestations of prejudice. To overcome this difficulty, a series of wide questions has been formulated and repeated in their objects of discussion, but from different terms and different point of views. It makes possible to identify contradictions among answers on different questions, which may suggest an internalization of discourses that are not rationalized and which come only from personal experiences or from common sense.

Through these strategies, it has aimed to investigate the initial hypothesis of this article, that is the existence of teachers who presuppose the students' performance from using or not using standard language in their speech. Such posture may contribute to the poor performance of the students since by 
underestimating the potential of the learners, the teacher could discourage them on learning or participating in class activities.

In a positive revelation of that, despite appearing as a suggestion of answer, not one teacher has been in favor of the given answer which says that "using Portuguese correctly in school is characterized by speaking only formal Portuguese in school activities" (our translation). A big part (66.7\%) of them, have answered they only demand the formal language in written works, which suggests the understanding of the idea of adequacy. The exemplary answers (22.2\%), however, argued that the correct use of Portuguese in school is characterized by "speaking and writing using formal and informal Portuguese according to the communication context" (our translation), and "knowing how to use the language in an appropriately towards intentionality and necessity" (our translation).

Meaningfully, 55.6\% of the interviewees have stated that they freely allow the use of slangs in classroom, some acknowledging that they "reveal traits of the culture of a certain group of speakers" (our translation), but they emphasize that students have to be able to adapt their speech in order to keep the respect to themselves, to the teacher, the classmates, and do not hurt the human rights, offending, or vilifying any person. Others, have said that "it is important that students interact with their own reality and, in this way, to contrast the formality with informality" (our translation), so the interviewees think communication in their own reality and community is very positive on establishing and on consolidating relationships. Parallel to this, $33.3 \%$ of the interviewees have said they allow the use of slang as long as it makes sense in the context of the activity, which is positive as well, because it brings to the students an idea that in each circumstance they need to require different uses of language. Only $11.1 \%$ of the teachers have answered that they did not allow slang to be used at any time, not opportunizing any kind of informal or slangs in interaction among the students in the classroom.

The same results that show greater receptivity to the idea of adequacy in school environment, also proved that $100 \%$ of the teachers, regardless of education or age, recognize the importance of teaching the formal language at school, disarticulating perspectives that look for relate the linguistic prejudice and the concept of adequacy as a possible "drop in education quality" or "decreasing" in the evaluations of the students in Portuguese Language classes. Such unfounded criticisms could be seen in commonsense discourses and printed media, such as newspapers and magazines, at a time when Brazilian Department of Education's books began to bring linguistic prejudice as a subject to the classroom. Some examples of printed media that show and outdated concept about this subject are "Book adopted by MEC (Brazilian Department of Education - our translation) defends speaking wrong" (our translation), posted by Estadão newspaper website on May, 12 ${ }^{\text {th }}, 2011$, and "MEC distributes book that accepts Portuguese errors" (our translation), published by O Globo paper website on June, $14^{\text {th }}, 2011$. These articles, maybe, have tried to hold the idea that standard language, written or spoken, have to be kept no matter any instance.

On the other hand, can be recognized the teachers' efforts on fighting and overcoming linguistic prejudice and this obsolete perspective of teaching Portuguese language in class, around the ones who have answered the interviews, but they have confessed that these kinds of attitude are not enough to solve the problem. When the teachers have been questioned about the affirmation "The Portuguese language that students bring from home is 'too informal"' (our translation), 77.8\% of the interviewee said they have absolutely agreed with the statement, although they have stated, later, that "students using slangs and too informal language in their social relationships do not harm their learning or teachers and classmates' relationships" (our translation). At the same time, it is worrisome that some members of the corpus attribute "too informal" students' language to a supposed "lack of personal and collective 
content" (our translation) or, in another case, in teachers' opinions, it happens because students who have free access to virtual chats and social networking websites start using informal language and slangs at an earlier age.

Other worrying results of the research have been the big group of interviewees who have related language flaws to learning problems, about $44.4 \%$ of them, and, finally, a high percentage of the teachers have agreed unequivocally that "students can reach better classroom grades using formal language" (our translation), around $55.6 \%$ of them. In that last question, only $22.2 \%$ of the teachers have disagreed with the statement of the question and presented arguments in accordance with the concept of adequacy, arguing that such "better results" are reached when the students are able to choose when and how to use better the language on their communication.

These results also allow for unforeseen readings and, consequently, new hypotheses and research possibilities. There are evidences, for example, of a scenario in which teachers who are graduated in Languages have a similar discourse about using Portuguese language, tending towards to opinions against linguistic prejudice. In fact, 33.3\% of the interviewees, the ones who are graduated and experienced in teaching language, have given answers that are aligned with the position defended by the theoreticians and researchers mentioned in the theoretical foundation of this study. If it could be checked, it would show the result of a huge effort of universities and higher institutions on approaching and discussing about linguistic prejudice, even though it is a recent concept in academia.

Corresponding to that, another possibility of study and research would be the exploration of relation the time that teachers' last academic formation have occurred thus prevalent or infrequent linguistic prejudice behaviors in classroom. This rendering has occurred when the authors of this study realized that teachers who did not agree with the statement, as well as being graduated in Languages, they have been graduated less than ten years ago, differing from the responses of the ones with a longstanding graduation. This conjecture suggests, then, that if this same analysis has embraced only among language teachers with academic formation in Languages, it might present important results, which could support the hypothesis on time of graduation and concepts about linguistic prejudice in classroom.

\section{FINAL CONSIDERATIONS}

A research is pertinent when it is anchored in relevant theoretical support and when it denotes lack of study about certain subjects. Based on this presupposition, associated to epistemological curiosity about linguistic prejudice, linguistic variation, adequacy and sociolinguistic studies, this work quested to research and to understand the intricated process between linguistic prejudice and teaching practice. This article has intended to know if, according to Bagno's (2007), Marcuschi's (2007), and Tarallo's (2010) studies about linguistic prejudice, and if teachers from different fields of teaching and from different schools, commit linguistic prejudice on their own classroom practice.

During the period of theoretical research, it has become very clear that a significant number of tendencies seek to clarify what is meant by linguistic prejudice, however, because it is an object of multiple use and interpretation, and because of it deriving countless social, cultural, and interactional ramifications, and to understand how and some reasons why linguistic prejudice occurs and manifests itself, so, it has proved to be a very complex task.

The issues arising from the initial hypothesis and the execution of the interview stages foreseen in the methodology of this article, allowed the analysis of collected results and the achievement of a 
scientific view about teachers' behavior and their perception related to the students' used Portuguese language, written or spoken, in school environment.

Through this research, some common tendencies have been identified, such as the marginalization of informal language used by students and the opinion of the interviewees that standard language is the best model language to be aimed, supposing the consensus among the interviewees that, through its use, students can be able to reach better learning results, they considering the use of "too informal" language as a weakness in their learning.

Thus, school continues contributing to keep the linguistic prejudice, considering correct the variacy of dominant classes as correct and the others (informal language) as mistakes to be surmounted, something which can contribute to the students' low self-esteem and then it may negatively meddle on their learning. Through this study, the authors hope they have noticed that social conventions, which privilege traditional grammar teaching instead of multiple language variations, do not addressing the issues of language heterogeneity, they can bring the linguistic prejudice subject to the classrooms, mainly to Portuguese language classes, opening space for discussion, acknowledgment and legitimation of differences and variation in Portuguese language.

\section{REFERENCES}

BAGNO, M. Preconceito linguístico - o que é, como se faz. 49 ed. Loyola: São Paulo, 2007.

BANDEIRA, L.; BATISTA, A. S. Preconceito e discriminação como expressões de violência. Rev. Estud. Fem., Florianópolis, v. 10, n. 1, p. 119-141, Jan. 2002. Available in:

$<\mathrm{http} / / / \mathrm{www}$. scielo.br/scielo.php?script=sci_arttext\&pid=S0104026X2002000100007\&lng=en\&nrm=iso>. http://dx.doi.org/10.1590/S0104-026X2002000100007. Access on May, $1^{\text {st }}, 2017$.

BESSA, J. C. R. Intolerância contra o linguista no discurso do senso comum. Lingüística, Montevideo, v. 31, n. 2, p. 47-60, nov. 2015. Available in: $<\mathrm{http} / / / \mathrm{www}$. scielo.edu.uy/scielo.php?script=sci_arttext\&pid=S2079312X2015000200004\&lng=es\&nrm=iso>. Access on May, $1^{\text {st }}, 2017$.

DA SILVA, A. R.; DA SILVA, J. R. O preconceito linguístico no ambiente escolar: como prevenir?. 2015. 34 f. Monografia (Licenciatura em Letras - Português/Inglês) - Universidade Federal do Oeste do Pará, Almeirin, Pará, Brasil, 2015.

ESTADÃO. Livro adotado pelo MEC defende falar errado, 12 de mai. 2011. Available in:< http://www.estadao.com.br/noticias/geral,livro-adotado-pelo-mec-defende-falar-errado,718471>. Access on June, $13^{\text {th }}, 2017$.

MARCUSCHI, L. A. Da Fala para a Escrita: atividades de retextualização. São Paulo: Cortez, 2007.

MARIANI, B. Entre a evidência e o absurdo: sobre o preconceito linguístico. Letras, Santa Maria, v. 18, n. 2, p. 19-34, jul./dez. 2008

O GLOBO. MEC distribui livro que aceita erros de português, 14 de jun. 2011. Available in: $<$ https://oglobo.globo.com/sociedade/educacao/mec-distribui-livro-que-aceita-erros-de-portugues2789040>. Access on June, $13^{\text {th }}, 2017$.

"preconceito". Dicionário Priberam da Língua Portuguesa on line (2008-2013.), Disponível em: $<$ https://www.priberam.pt/dlpo/preconceito $>$. (April, 27 $7^{\text {th }}, 2017$ ). 
PRODANOV, C. C.; FREITAS, E. C. Metodologia do trabalho científico: métodos e técnicas da pesquisa e do trabalho acadêmico. 2. ed. Novo Hamburgo, RS: Feevale, 2013. 276 p. Available in: <http://www.feevale.br/Comum/midias/8807f05a-14d0-4d5b-b1ad-1538f3aef538/E-

book\%20Metodologia\%20do\%20Trabalho\%20Cientifico.pdf $>$. Access on June, $1^{\text {st }}, 2017$.

SANTANA, J.; NEVES, M. As Variações Linguísticas e suas Implicações na Prática Docente. Millenium, 2015.

TARALLO, F. A pesquisa sociolinguística. 8a ed. São Paulo: Ática, 2010. 93 p.

TRAVAGLIA, L. C. A gramática na escola / Língua Portuguesa: o ensino de gramática. Salto para o Futuro, Boletim, v. 3, p. 73-97, 2007. 